\title{
Linguocultural Peculiarities of British Parliamentary Discourse
}

\author{
Samvel Abrahamyan \\ Yerevan State University
}

\begin{abstract}
Peculiarities of British parliamentary discourse are largely conditioned by context models of its participants, which influence the style and linguistic forms of their speeches. As context models are culturally predetermined, linguistic means used in parliamentary discourse have also certain linguocultural peculiarities. Centuries-old traditions of British parliamentary system find their reflection in the language and form an essential part of British parliamentary discourse. The adherence to these communicative norms, including different rituals, ceremonies and traditions peculiar to British political life and British political discourse, has a special symbolic meaning and is aimed at maintaining stability of the political system, respect for the state power and its authority.
\end{abstract}

Key words: political discourse, British parliamentary discourse, context models, the form and style of British parliamentary debates, linguocultural peculiarities.

\section{Introduction}

Nowadays the importance of language, in the sense of differential verbal formulation, is acknowledged by political parties and government agencies which employ publicists of various kinds, whose role is not merely to control the flow of, and access to information, but also to design and monitor wordings and phrasings, and in this way to respond to challenges or potential challenges (Chilton 2004:8). In the era of spin, when political discourse is characterized by high degree management and manipulation, in order to understand the political meaning of a speech it is important to pay attention to its context. According to Dijk, though genres are connected with certain grammatical structures, their characteristics are to a larger extent contextual rather than textual. It means that, for example, parliamentary debates are defined not so much by topic, formal style and discursive restrictions, as all these can occur in other discourses as well, but by the roles and 
identities of participants (members of parliament), their relations (e.g. supporters of the ruling party against opposition), their goals and actions. Trying to understand any political speech it is necessary to take into account "who speaks to whom, as what, on what occasion and with what goals. In other words, political discourse is especially "political" because of its functions in the political process" (Dijk 2002:225).

\section{Linguocultural Models in Parliamentary Discourse}

The contexts of political discourse are formed by context models which are cognitive constructs of the participants of the discourse. As context models are connected with non-linguistic reality they are characterized by definite national cultural peculiarities which influence linguistic models of political discourse. For example, speeches of members of parliament during parliamentary debates are strictly regulated by parliamentary procedures many of which are culturally marked and reflect centuries-old traditions of the British parliamentary system.

The origins of Parliament go back to the 13th century: there are many rules, customs and traditions that help explain its workings. Much of parliamentary procedure has developed through continued use over the centuries and is not written in the Standing Orders. This is sometimes known as "custom and practice." For example, the practice of bills being "read" three times in both Houses is not in the Standing Orders. Other procedures have developed through precedents such as rulings made by the Speaker and resolutions of the House. Erskine May, who was the Clerk of the House of Commons between 1871 and 1886, wrote "Treatise on the Law, Privileges, Proceedings and Usage of Parliament" which is considered the authoritative source on parliamentary procedure. This book, which is now in its 24th edition, provides details of observed "rules" within the House, whether they relate to Standing Orders (and are therefore regulated by the House), traditional practice or whether they derive from "Speaker's Rulings" (Rules and Traditions of Parliament 2015).

The way in which debates are held in British Parliament is governed by the Standing Orders, the written rules which regulate the proceedings of each House, and also by various customs and traditions (Parliament Explained 2007). The majority of MPs are well aware of parliamentary procedures which include specific forms of address, formulas of etiquette, style of speech characteristic of parliamentary debates, as well as in communicative behavior of the participants of the debates. For example, the members of the House of 
Commons during the debate can speak only when addressed by the Speaker. Those who want to speak should try to attract the Speaker's attention by rising to their feet.

This procedure is called "catching the Speaker's eye". When the Speaker calls on a Member to speak, the other MPs who rose at the same time will then sit down. Only one Member is allowed to stand and speak at any one time. If a Member wishes to interrupt a speech, he or she will rise to their feet. The Member who is speaking may then sit down and allow an interruption - known as an "intervention"- to be made in his or her speech, but if he or she refuses to give way, then the Member wishing to interrupt should sit down (Parliament Explained 2007:4).

This kind of procedure of conducting parliamentary debates is an example of constitutional convention which is an informal and uncodified procedural agreement which is adhered to by state institutions and, in particular, by the House of Commons. It is in fact an example of a context model used by the MPs to which former British Prime Minister D. Cameron explicitly alluded at the beginning of his speech on Syria in the House of Commons on 2 December 2015. He said: "Mr Speaker, I will take dozens of interventions in the time that I have. I am conscious of not taking up too much time as so many people want to speak, but I promise that I will give way a lot during my speech. Let me make a bit of progress at the start" (Hansard. House of Commons, Vol. 603, col. 324).

According to the official Hansard transcripts, D. Cameron during his above mentioned speech gave way 28 times. As a result of adhering to such a procedure the speech of the speaker assumes the form of a polylogue rather than monologue or dialogue.

This style of debate can make the Commons Chamber a rather noisy place with robustly expressed opinion, many interventions, expressions of approval or disapproval and, sometimes, of repartee and banter (Rules and Traditions of Parliament 2015).

Sometimes during the debates tempers rise and several MPs may try to shout at once. The Speaker then has to exert the Chair's authority. If tempers become heated, it is the chairman who will step in to control the debate. The Speaker or Deputy Speaker would say "Order, Order" trying to bring the House under control again (Parliament explained 2007:4). 
Ultimately it is the Chair, The Speaker of the House of Commons, who controls the House and who speaks and when. Members have the right, when speaking, to be heard without unendurable background noise (deliberate or accidental) and the Chair will call for order if it appears there is an attempt to drown out a Member or when a number of Members are leaving the Chamber, or conversing loudly (Rules and Traditions of Parliament 2015).

After the principal speakers anyone else wishing to speak can then rise and make their contribution. Members may speak only from where they were called and they may not speak from the floor of the House between the red lines which they are not allowed to cross during debates. They must stand whilst speaking but if they are unable to do so they are allowed to address the House seated (Parliament explained 2007:2).

Whilst front-benchers may, if they wish, speak from the Despatch Boxes on the table in front of the Speaker, all other Members rise to speak from wherever they are sitting in the House (Parliament explained 2007:3). MPs address all their comments to the chairman, not to each other. MPs are not allowed to refer to each other by name and instead always refer to "the honourable member for..." the place they were elected to. If one can't remember where someone is MP for he or she can refer to them as "the honourable gentleman" or "the honourable lady".

If someone from the same party is talked about, they can be referred to as "my honourable friend", while members of the privy council - usually ministers - are "the right honourable". The exception to this is the Speaker, who can refer to anyone he likes by name. MPs are only allowed to speak to one person in the House of Commons: the Speaker. Nobody else is ever directly addressed. This is why politicians talk in the way that they do, beginning their sentences with "Mr Speaker" (or "Madam Speaker"), and referring to "he" or "she" instead of "you" when making points about their opponents or friends in a debate (Oxford Guide to British and American Culture 2000: 504). Normally MPs or Lords may speak only once in a debate, although MPs may "intervene" with a brief comment on another MP's speech. Lords normally speak only once, except to give clarification or by special leave (Debates 2016).

As already mentioned MPs do not use personal names, but refer to another MP as "my right honorable friend", "the honourable Member for...." This practice was originally intended to prevent MPs getting too angry with each other (Oxford Guide to British and American Culture 2000:405). Still the forms of 
addresses have some peculiarities. MPs from the same party refer to each other during the debates as "my right hon. Friend", including the cases when they refer to the Prime Minister. The latter refers to MPs from his own party as "my hon. Friend", "my right hon. Friend" or "my right hon. and learned Friend". The Prime Minister refers to MPs from other parties, including the leader of opposition as "the right hon. Gentleman" or "the hon. Lady" or "the right hon. and learned Lady".

In the House of Lords the accepted forms of address are My Lords, noble Lords, the noble Lord, the noble Baroness (e.g., the noble Lord, Lord Brooke; the noble Baroness, Lady Evans, but it is also possible to use the form of address without mentioning the name). The members from the same party address each other as my noble friend (e.g., my noble friend, Lord Brooke).

Not all MPs, especially newly elected are well aware of those parliamentary rules and conventions, that's why the Speaker, or a Deputy Speaker, from time to time has to intervene in the debates to ensure that the rules of the House are adhered to. Sometimes explanations are given as in the following example:

Ruth Cadbury (Brentford and Isleworth) (Lab): I thank the previous speaker, the hon. Member for Aldershot (Sir Gerald Howarth), who is also my constituent, but I am afraid I am going to disagree profoundly with you.

Madam Deputy Speaker (Mrs Eleanor Laing): Order. The hon. Lady is not going to disagree with the Chair. She might disagree with the hon. Gentleman, but she will not disagree with the Chair. I am clamping down on this now, because we have been here a long time.

Ruth Cadbury: My sincere apologies, Madam Deputy Speaker. I am still getting used to the conventions of this place.

(Hansard. House of Commons, Vol. 602, col.1559)

In the example above the Deputy Speaker rebukes the MP for not adhering to the rules of the House using the negative politeness strategy and trying to save as much as possible the face of the addressee. It is manifested in the implicit expression of the reproach used with a regulative function which is provided not only by lexical and syntactical units, but also by grammatical forms, e.g., by using such forms as "is not going to" and "will not" instead of usual for the speech acts of reproach modal verbs should or ought with perfect infinitive. 
It should be also noted, as mentioned above, that British parliamentary discourse has a mediated character as the MPs while speaking address not directly the addressee but the Speaker. It results in using the models peculiar to indirect communication, e.g. using personal pronouns "he" or "she" instead of "you" (It doesn't refer to the Lords who normally address not the Lord-speaker, but all the members of the chamber using the expression "My Lords"). According to the official video record during the debates on Syria on September 7, 2015 Prime Minister D. Cameron in his answer to the speech of the leader of the opposition Harriet Harman pronounced the expression "the right hon. and learned Lady" only once, pronoun "she" - 14 times, pronoun "her" - 4 times (Parliamentlive.tv 2016).

However, in the official transcript of the debates (Hansard) in ten cases the pronouns "she" and "her" were substituted by the expression "the right hon. and learned Lady" as a result of which pronoun "she" occurs in the text only 6 times. This example illustrates differences between spoken and written language. If in his speech David Cameron allowed himself to use the pronoun "she" 14 times referring to Harriet Harman, sitting just in front of him, in the official transcript of the debates it was found unacceptable.

In his speech D. Cameron used pronouns "we" and "I" 35 and 15 times correspondingly, the former being used in its exclusive meaning, i.e. without including the addressee. It had the highest frequency of all the nominal words $(2.83 \%)$ and was opposed to the pronoun "she" with the implicit meaning that the speaker (D. Cameron) expresses the opinion of the majority, whereas the opposite side is in the minority.

It is necessary to take into account the specific features of the genre of parliamentary debates in British parliament. Though for parliamentary debates the formal communication style (as an example of formal style T.A. van Dijk brings the following sentence uttered by T. Blair's in the House of Commons during the debates on Iraq: "I do not disrespect the views in opposition to mine" where the expression "in opposition to mine" is used instead of "opposed") (Dijk 2008:2) is predominant, parliamentarians often shift to informal communication style as in British Parliament speeches should not be read and only notes can be referred to. Even in case of statements made by principal speakers, which are usually prepared in advance and are written in formal style, while answering the questions they have to turn from formal style to conversational. For example, D. Cameron after his statement on Syria and counter terrorism while answering to 
H. Harman used such colloquial words and expressions as "I would say", "What is going to happen here is", "What I would say is", "Look" (to attract attention), "I think" etc. None of them, except "I think", were included in the official Hansard record.

In the Hansard record the expressions I think, I thought used in Cameron's answer were half the number (6/12) of the same expressions used in his speech as recorded in the official video. In his official statement on Syria and counter terrorism (Hansard Vol. 599, col. 23-27), which was read by D. Cameron not long before his answer to H. Harman, the expression "I think" was used only once as a citation form his previous speech delivered a year before. And it is not surprising as in political communication, the main goal of which is the persuasion of the audience, the speaker's speech should be confident and argumentative.

As mentioned above there are certain differences in parliamentary rules and conventions of the House of Lords as compared with the House of Commons. Unlike the Speaker of the House of Commons, the Lord Speaker is politically neutral and is elected by Members of the House. The Lord Speaker does not control the proceedings during a debate. You will never hear the Lord Speaker shouting "Order, Order" as it is assumed that the Lords themselves will keep order during their debates. On the whole, debates in the House of Lords are calmer than those in the Commons. If, however, the temperature did rise, there would be a chorus of "Order, Order", from Lords sitting all round the Chamber, rather than from the Lord Speaker.

Another difference between the Lord Speaker's position and that of the Speaker of the House of Commons is that he/she does not decide who shall speak next in a debate: the practice of "catching the Speaker's eye" in the House of Commons has no equivalent in the House of Lords. Instead, there is a list of speakers. The order of speaking will have been arranged in advance by agreement between the party Whips, together with a representative of the Crossbenchers - those who sit on the crossbenches, between the Government and the Opposition, and have no party ties (Parliament explained 2007:7).

If a number of Members rise to speak at the same time, most of them will normally sit down immediately, allowing the remaining Member to speak. If however, more than one Member remains on his feet, there will be cries of "Order, Order" from all around the Chamber. This usually encourages all but one to sit 
down. The remaining Member will then speak. (Parliament explained. Debates in Parliament 2007:8).

Unlike the House of Commons, where all speeches are directed towards the Speaker, all speeches in the Lords are addressed to the House in general and begin "My Lords". If one Lord making a speech wishes to refer to another Member, he will do so in a particular way, e.g. "The Noble Lord, The Lord Bloggs", or in the case of a Baroness "The Noble Baroness, The Baroness Bloggs". This is rather like the procedure in the House of Commons where Members are not referred to by name. As in the House of Commons notes can be referred to, but speeches should not be read. Long speeches are discouraged (Parliament Explained 2007: 8).

\section{Conclusion}

In political communication producing and understanding text and talk involves what is traditionally called the "context" of the speech, involving such categories as participant identities and roles, place, time, institution, political goals, actions and political knowledge, among other components. Contexts also control discourse style, including the specific contextual constraints of the parliamentary debates. Appropriate background knowledge that lies in the basis of context models helps to make communication effective. These context models help understand that when referring to "The House" the speaker in the House of Commons deictically refers to "this" House of Commons where he is now speaking. In the same way when the speaker in the House of Lords deictically refers to "this place" and "the other place" the House of Lords and the House of Commons are correspondingly meant. Apparently, language and language use are of course social phenomena, and need to be studied in their social and cultural contexts.

Rules and conventions of British parliamentary discourse as well as different rituals, ceremonies and traditions that form part of British political culture and find their reflection in the language have important symbolic meaning and are aimed at maintaining the respect for the state power and its authority.

\section{References:}

1. Chilton, P. (2004) Analysing Political Discourse: Theory and Practice. London: Routledge. 
2. Crowther, J. (ed.) (2000) Oxford Guide to British and American Culture. Oxford: OUP.

3. Dijk, T.A. van (2008) Discourse and Context: A Sociocognitive Approach. Cambridge: CUP.

4. Dijk, T.A. van (2002) Political Discourse and Political Cognition. // Politics as Text and Talk. Analytic Approaches to Political Discourse. / Ed. by P. Chilton and Ch. Schäffner. Philadelphia, PA, USA: John Benjamins Publishing Company, pp. 203-236.

5. Debates. Available at: http://www.parliament.uk/about/how/business/debates/> [Accessed December 2015].

6. Hansard. House of Commons (2015), Vol. 599, col. 23-31.; Vol. 602, col. 1559; Vol. 603, col. 324.

7. Parliament Explained. Debates in Parliament. Parliamentary education service. 2007. Available at: <http://www.parliament.uk/documents/education/onlineresources/printed-resources/debates.pdf $>$ [Accessed November 2016].

8. Parliamentlive.tv. House of Commons. Monday, 7 September 2015. Available at: <http://www.parliamentlive.tv/event/index/a472a129-39b4-4c22-a8f4f0785e2cf856?in=15:30:16 > [Accessed September 2015].

9. Rules and Traditions of Parliament. Available at: <http://www.parliament.uk/ about/how/role/customs $>$ [Accessed December 2015].

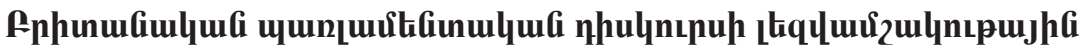 unufiáfiuhuunlynıpjnıficitipn}

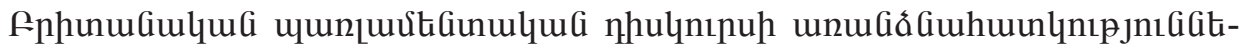

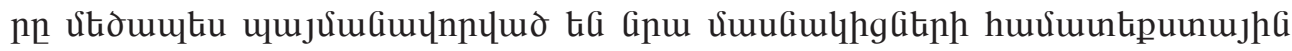

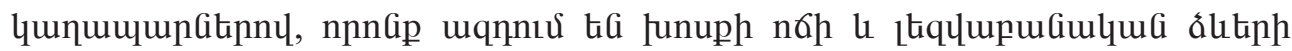

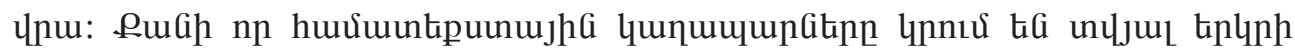

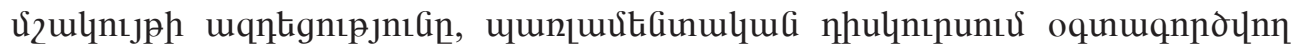

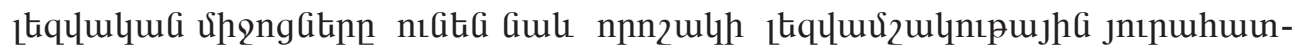
unıpjnıGitip:

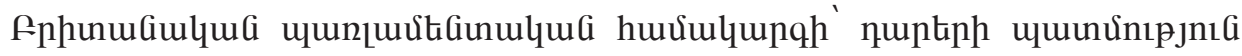

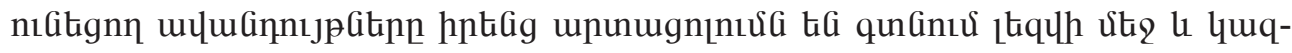

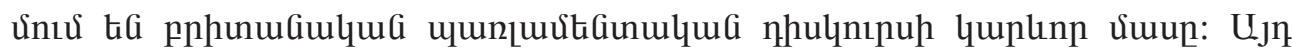

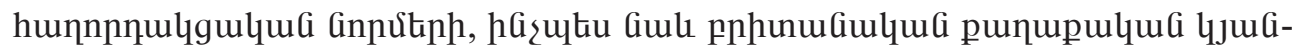




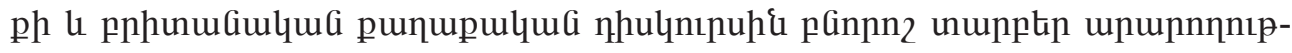

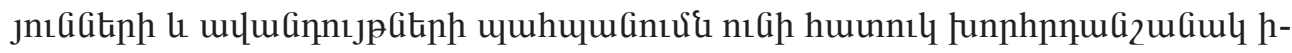

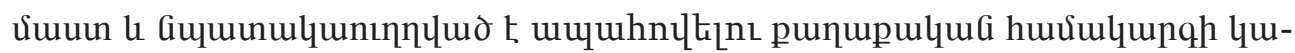


hupquipn: 